\title{
Détermination of the biodegradable fraction of dissolved and particulate organic carbon in waters
}

\author{
P. Servais 1 \\ A. Barillier ${ }^{2}$ \\ J. Garnier ${ }^{3}$
}

Keywords : Dissolved organic carbon, particulate organic carbon, total organic carbon, biodegradation, river water, vaste water.

A simple procedure is described in order to estimate the biodegradable fraction of dissolved organic carbon (DOC), particulate organic carbon (POC) and total organic carbon (TOC) in water samples. Methodological improvements of the method which includes aerobic incubation in batch and carbon measurements are presented. First applications to natural and waste water samples show the usefulness of the method in the field of water treatment and management of surface water.

Détermination de la fraction biodégradable du carbone organique dissous et particulaire dans les eaux douces

Mots clés : carbone organique dissous, carbone organique particulaire, carbone organique total, biodégradation, eau de rivière, eau usée.

Une procédure simple est décrite, permettant la détermination dans des échantillons d'eau de la fraction biodégradable du carbone organique dissous (COD), du carbone organique particulaire (COP) et du carbone organique total (COT). L'article présente des expériences justifiant la procédure retenue. Les premières applịcations de la méthode montrent son utilité à la fois dans le domaine du traitement des eaux usées et dans celui de la gestion des eaux de surface.

\section{Introduction}

Biodegradable organic matter (BOM) can be defined as the fraction of organic carbon which can be metabolised by bacteria within a period of a few hours to a few weeks. BOM is so the actual signal to which growth and activity of heterotrophic microorganisms respond in natural waters. Its knowledge is therefore required for understanding and modelling bacterial activity in aquatic ecosystems. As chemical analysis of organic compounds in natural waters is very complex and cannot give complete

1. Groupe de Microbiologie des Milieux Aquatiques (GMMA), Université Libre de Bruxelles, Campus de la Plaine, CP 221, boulevard du Triomphe, B-1050 Bruxelles.

2. CEMAGREF, Division Qualité des Eaux, 14, avenue de Saint-Mandé, F-75012 Paris.

3. CNRS, URA 1367, Laboratoire de Géologie Appliquée, 4, place Jussieu, Tour 26, 5 étage, F-75005 Paris. information on its biodegradability (Hama \& Handa 1980, Dawson \& Duursma 1981), the use of bioassay procedures is thus required in order to determine the biodegradable fraction of organic matter.

During the last decade, accurate analytical methods have been made available for accurate determinations of dissolved organic carbon (DOC) and particulate organic carbon (POC). As there was an increasing interest to estimate the biodegradable dissolved organic carbon (BDOC), especially in the field of drinking water production and distribution, several methods have been proposed in the literature to estimate BDOC as the difference of DOC before and after an incubation of the water sample in the presence of bacteria (see the review by Huck 1990). Among these methods, Servais et al. (1987, 1989) use indigenous suspended bacteria to inoculate the water sample while fixed bacteria onto sand or inert support are used as inoculum in the 
procedures proposed respectively by Joret \& Levi (1986) and Ribas et al. (1991). Block et al. (1992) have shown that the origin of the inoculum in this kind of bioassay was a low source of variance. However, these methods only concern the dissolved fraction of organic matter. In a lot of natural aquatic environments and in waste water, the concentration of particulate organic matter is often as high as the dissolved fraction or even higher ; in these conditions, it is therefore important to develop methods to estimate the biodegradable fraction of both particulate and dissolved organic carbon.

In this paper we propose a simple procedure based on carbon measurements to estimate the biodegradable fraction of DOC and POC in batch experiments. Briefly, the water sample is incubated in aerobic conditions, DOC and POC are measured at the beginning of the incubation (initial concentrations) and at the end of incubation (final concentrations) when the biodegradable fractions of DOC and POC have been mineralised by bacteria. The biodegradable dissolved organic carbon (BDOC) and biodegradable particulate organic carbon (BPOC) are determined as the difference between initial and final concentrations of DOC and POC respectively. The biodegradable total organic carbon (BTOC) is calculated as the sum of BDOC and BPOC. The paper first presents experiments performed in order to determine the incubation period in this kind of batch experiments required for bacteria to consume the biodegradable compunds and so to reach stable concentrations in DOC and POC. Data of BDOC determinations using the procedure described in this paper have been compared to data obtained on the same samples using the BDOC technique described by Servais et al. (1989).

As a first application, BTOC estimations were performed on raw and treated waste water effluents, data obtained on river waters are also presented.

\section{Materials and methods}

\subsection{BTOC determination in batch experiments}

The experimental procedure we proposed to determine in paralell the biodegradable fraction of DOC (BDOC) and of POC (BPOC) was as follows : just after collection, the water sample to be analysed (2 litres) was first sieved through a nylon membrane of $1 \mathrm{~mm}$ porosity and than incubated at $20+1-$ $0.5^{\circ} \mathrm{C}$; during the incubation the sample was intermittently oxygenated by air bubbling to insure aerobic conditions during biodegradation. To avoid carbon contamination by the aeration of the batch system, the air was previously bubbled in two successive bathes of sulfochromic mixture and one bath of distilled water before injection in the batch system. Subsamples were collected in the batch just after the beginning of the incubation and at regular periods of time for DOC and POC determinations. The batch was incubated for 45 days as we have shown that such a period was long enough to reach stable values of DOC and POC (see section 3.1 of the paper) ; the remaining organic carbon at this moment was considered as the refractory part of the organic matter. For DOC analysis, two subsamples of $30 \mathrm{ml}$ were taken out of the batch at each collection time and filtered through precombusted $\left(4\right.$ hours at $550^{\circ} \mathrm{C}$ ) fibreglass Whatmann GF/F filters ; DOC measurements were performed using carbon analysers (Dohrman DC180 or Biorotech 700). For POC analysis, three subsamples (4 to $20 \mathrm{ml}$ ) were filtered through a $1 \mathrm{~cm}$ diameter precombusted fibreglass filter (Whatman GF/F) using a syringe ; organic matter retained on the filters was determined using the Bioritech 700 analyser. The accuracy of the DOC and POC determinations were about $0.05 \mathrm{mgC} / 1$. BDOC and BPOC were calculated as the difference between concentrations, in DOC and $P O C$ respectively, at the beginning of the batch experiment and the stable values reached at the end of the incubation that were defined as the refractory fraction of DOC (RDOC) and of POC (RPOC). Total organic carbon (TOC) in the sample was calculated as the sum of DOC and POC at the beginning of the experiment and the biodegradable fraction of TOC (BTOC) as the sum of BDOC and BPOC.

\subsection{Determination of BDOC following the Servais et al. (1989) procedure}

After a prefiltration through a WHATMAN GF/F precombusted filter, a $200 \mathrm{ml}$ water sample was sterilized by filtration through a $0.2 \mu \mathrm{m}$ pore size membrane (Nuclepore membrane or cellulose acetate Sartorius membrane) carefully rinsed first with distilled water $(300 \mathrm{ml})$ and then with the water sample $(100 \mathrm{ml})$. A $2 \mathrm{ml}$ inoculum containing indigenous bacteria was added; the inoculum was in 
fact water, from the same environment as the sample, filtered trough a $2 \mu \mathrm{m}$ pore size membrane (Nuclepore membrane). Incubation of the inoculated sample was performed at $20+/-0.5^{\circ} \mathrm{C}$ in the dark for 4 weeks on a shaking table. A strong agitation allowed to avoid oxygen depletion during the incubation of samples with high BDOC. Two $30 \mathrm{ml}$ subsamples were collected at the beginning of the incubation (just after the addition of the inoculum) and at the end of the incubation for DOC determinations that were performed using the Dohrman DC180 carbon analyser. The BDOC values were calculated as the difference between initial and final $D O C$.

\section{Results and discussion}

\subsection{Methodological improvement}

Figure 1 shows an example of the fluctuations of DOC, POC and TOC during a batch experiment performed following the here above described procedure with an urban effluent from Brussels. It contained at the beginning of the experiment $49.4 \mathrm{mgC} / 1$ of $\mathrm{POC}$ and $25 \mathrm{mC} / 1$ of DOC. A rapid decrease of DOC was observed during the first day of incubation when $6.3 \mathrm{mgC} / 1$ were consumed in 24 hours; this corresponds to a first order rate of $0.3 \mathrm{~d}^{-1}$. The average decrease rate of DOC was $0.08 \mathrm{~d}^{-1}$ for the first week of incubation. The concentration in DOC reached a stable value, at the accury of the measurement method, between 20 and 30 days of incubations. For the POC, the average decrease rate for the first week of incubation was a little lower than for DOC $\left(0.65 \mathrm{~d}^{-1}\right)$.' Then, POC decreased more slowly (decrease rate around $0.01 \mathrm{~d}^{-1}$ between day 7 and day 30 of incubation). The plateau was reached between 30 and 45 days of incubations.

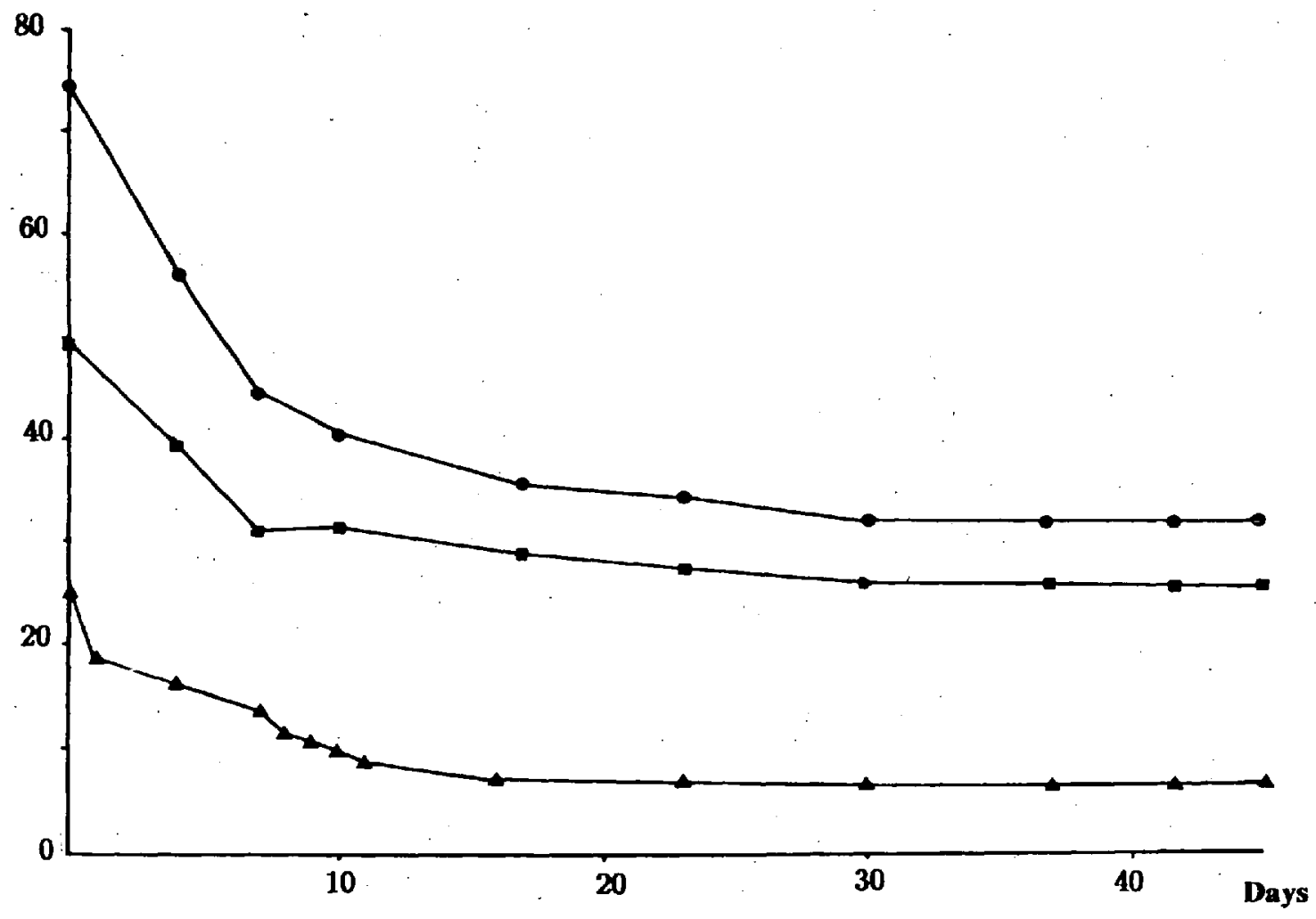

Fig. 1. Fluctuations in DOC (A), POC (a) and TOC (O) concentrations during a batch experiment performed with a sample of urban effluent (Brussels, March 1992).

Fig. 1. Fluctuations des concentrations en $\operatorname{COD}(\mathbf{A}), \operatorname{COP}(\boldsymbol{\Xi})$ et COT $(\odot)$ durant une expérience batch réalisée sur un échantillon d'eau usée urbaine (Bruxelles, mars 1992). 
The concentrations of DOC and POC reached at the end of the incubation were respectively 6.4 and $24.6 \mathrm{mgC} / 1$. BDOC was thus equal to $18.6 \mathrm{mgC} / 1$ (74.4\% of the initial DOC) and BPOC to $24.8 \mathrm{mgC} / 1$ (50.2 \% of the initial POC). The biodegradable fraction of the TOC was so for this sample $43.4 \mathrm{mgC} / 1$ ( $58 \%$ of the initial TOC).

Series of similar experiments were carried out with waste water samples from different treatment plants and with samples collected in rivers. In all the tested samples, constant values of DOC and POC were reached before 45 days of incubations as for the experiment described in figure 1 . So for routine measurements we decide to fix the incubation period to determine BTOC to 45 days.

On a series of eleven samples of natural and waste waters, BDOC was estimated using two different procedures. On one hand, they were estimated using the procedure proposed by Servais et al. (1989) in which the sample is filtered and reinoculated with indigenous suspended bacteria before the beginning of the incubation and, on the other hand, using the procedure proposed in this paper for estimating in parallel BDOC and BPOC. Major differences between these two techniques lies, first, in the presence or the absence of the particulate fraction of the organic matter during the course of the incubation, secondly in the incubation period, 45 days versus 30 days and, lastly, in the fact that DOC is considered as the fraction passing through a $0.7 \mu \mathrm{m}$ pore size membrane (Whatman GF/F filter), in one method, and through a $0.2 \mu \mathrm{m}$ pore size membrane, in the other one. In figue 2 , the BDOC values determined using one method were plotted agains the BDOC data determined using the other methods. A very significant correlation was observed $(r=0.99$, $\mathrm{n}=11$ ). The slope of the correlation straight line (1.03), very close to 1 , indicated that there was no significant difference between both estimates of BDOC. In other words, this means that :

- The presence of the particulate organic matter during the incubation does not seem to influence the BDOC data, i.c. POC does not act as a cosubstrate for further degradation of DOC (Barillier \& Garnier, 1993). Moreover, it is important to note that, if a fraction of $P O C$ is solubilized during the incubation, it as also mineralised before the end of experiment.

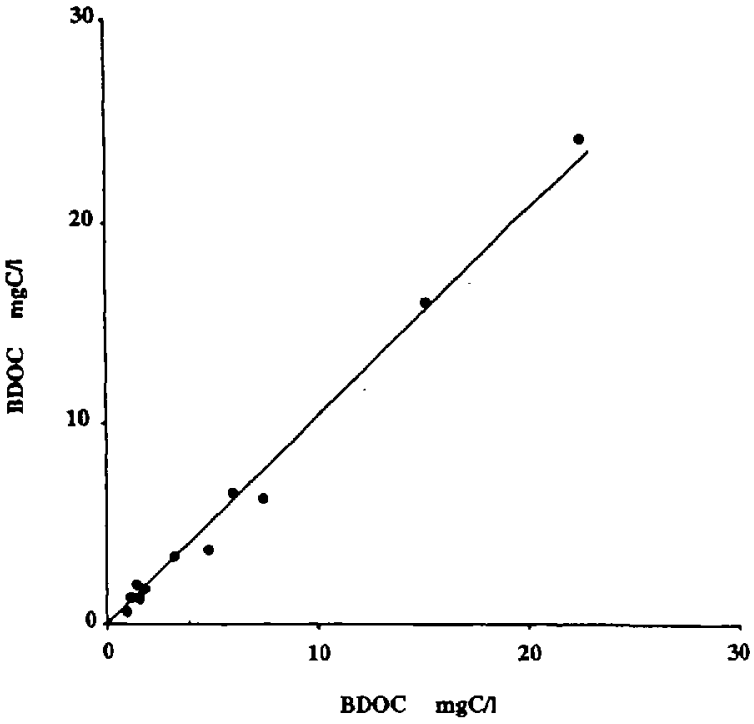

Fig. 2. BDOC values measured using the procedure proposed in this paper ( $y$ axis) plotted against BDOC values estimated on the same samples of waste waters and river waters using the Servais et al. (1989) method ( $x$ axis).

Correlation straight line : $y=1.03 x \quad(r=0.99, n=11)$

Fig. 2. Valeurs de CODB estimées selon la procédure proposée dans cet article (axe Y), portées en fonction des valeurs de CODB estimées sur les mêmes échantillons d'eaux usées et de rivières par la méthode proposée par Servais et al. (1989) (axe $\mathrm{x})$.

Droite de régression : $\mathrm{y}=1.03 \mathrm{x} \quad(\mathrm{r}=0.99, \mathrm{n}=11)$

- The $\mathbf{3 0}$ day incubation period is long enough to consume the entire biodegradable fraction of DOC as already pointed out by Servais et al. (1989) and in the previous section of this paper.

- The fraction of organic carbon in the size range between 0.7 and $0.2 \mu \mathrm{m}$ is insignificant. This results is in concordance with the data of Barillier (1992) showing that around $1 \%$ only of the total organic carbon was in this size range for various waste waters and river waters.

\subsection{BTOC determination in different water samples}

In addition to the measurement performed on the Brussels effluents, BTOC was also determined on raw and treated water of the Achères treatment plant collected in June 1992 (Table 1). This plant located in the Parisian suburbs is the most important treatment plant in Europe ; it receives the waste water of about 8.000 .000 equivalent inhabitants and 
Table 1. Concentrations in the different fractions of organic carbon expressed in $\mathrm{mgC} / \mathrm{l}$ (dissolved $\mathrm{D}$, particulate $\mathrm{P}$ and total $\mathrm{T}$ ) in the tested wastewaters and river water samples ( $B$ for biodegradable and $\mathbf{R}$ for refractory fractions).

Tableau 1. Concentrations des différentes fractions du carbone organique exprimées en mgC/l (D pour dissoute, $\mathrm{P}$ pour particulaire et $T$ pour total) dans les échantillons d'eaux usées et de rivières analysées ( $B$ pour biodégradable et $R$ pour réfractaire).

\begin{tabular}{|c|c|c|c|c|c|c|c|c|c|c|}
\hline & 1992 & DOC & BDOC & RDOC & POC & BPOC & RPOC & TOC & BTOC & RTOC \\
\hline \multicolumn{11}{|c|}{ Waste water samples } \\
\hline Achères-raw water & June & 33.00 & 24.35 & 8.65 & 43.00 & 26.40 & 16.60 & 76.00 & 50.75 & 25.25 \\
\hline Achères-treated water & June & 26.45 & 16.15 & 10.30 & 21.25 & 13.05 & 8.20 & 47.70 & 29.20 & 18.50 \\
\hline Brussels-raw water & March & 25.00 & 18.60 & 6.40 & 49.40 & 24.80 & 24.60 & 74.40 & 43.40 & 31.00 \\
\hline
\end{tabular}

River water samples

\begin{tabular}{lccccccccccc}
\hline Seine river (La Frette) & June & 4.40 & 1.20 & 3.20 & 2.15 & 0.55 & 1.60 & 6.55 & 1.75 & 4.30 \\
\cline { 2 - 10 } Seine river (Bac) & June & 8.45 & 4.35 & 4.10 & 5.15 & 2.45 & 2.70 & 13.60 & 6.80 & 6.80 \\
\cline { 2 - 9 } Meuse river (Liège) & May & 5.10 & 2.00 & 3.10 & 4.10 & 1.25 & 2.85 & 9.20 & 3.25 & 5.95 \\
\hline
\end{tabular}

treatment includes classical pretreatment and decantation followed by an activated sludge stage. The treated effluents of this plant are discharges into the river Seine and constitute the main source of organic matter to the river downstream Paris (Garnier et al. 1992, Servais \& Garnier 1993).

In the raw waters, DOC and POC equalled respectively $33 \mathrm{mgC} / 1$ and $43 \mathrm{mgC} / \mathrm{l}$ (Table 1 ) and the biodegradable part represented $74 \%$ for DOC $61 \%$ for POC (67\% for the total organic carbon). These values are comparable with those obtained on the raw waters of Brussels.

Regarding the treated water, DOC and POC were 26.45 and $21.25 \mathrm{mgC} / 1$ corresponding to a removal by treatment of $6.55 \mathrm{mgC} / 1$ of DOC $(20 \%)$ and $21.75 \mathrm{mgC} / 1$ of POC (51 \%). The biodegradable fractions of the treated waters represented $61 \%$ for DOC and $61 \%$ also for POC.

The removal of DOC during treatment was approximately similar to the removal of BDOC $(6.55$ against $8.2 \mathrm{mgC} / \mathrm{l})$ showing that the treatment removes the dissolved fraction through a process of biodegradation rather than through a physicochemical process. The mechanism of removal is different for POC. The removal of POC during treatment was much higher than the removal of BPOC ( 21.75 against $13.35 \mathrm{mgC} / \mathrm{l})$, but the percentage of POC and BPOC removal are very similar, indicating that the refractory and the biodegradable fraction of POC was proportionally removed with same efficiency. That means that the impact of biodegradation of particular organic matter in activated sludge was low with respect to the decantation that was the major process in removing POC.

BTOC was also estimated on three river waters. River Seine was sampled just upstream (LaFrette) and downstream (Bac) the effluent outfall from the Achères treatment plant ; a sample was also collected in the River Meuse (Belgium) in an organically polluted area near Liège (Table 1). In the River Seine, the biodegradable fraction of TOC, increased from $27 \%$ upstream to $50 \%$ downstream the effluent outfall. In the River Meuse sample, an intermediate value of $35 \%$ of biodegradable TOC was found ; BTOC was composed of $62 \%$ of dissolved material and $38 \%$ of particulate one.

Regarding all the results, it appears that the importance of the BTOC fraction is associated with the degree of domestic pollution. Quantifying the biodegradable fraction of organic matter gives insights on the bacterial activity that can be supported. 


\section{Conclusion}

The proposed method to determine simultaneously the biodegradable fraction of TOC, DOC, $P O C$ is very easy to apply from a laboratory point of view. In routine, it only requires the measurement of DOC and POC at the beginning and at the end of the experiment. During the incubation period that is performed at laboratory temperature, the only thing to do is to control the oxygenation of the sample.

This method can be considered as an alternative to the classical method of the biological oxygen demand (BOD) used for estimating biodegradable matter in waste water samples. As main differences between both methods, we have to mention the next points. The data obtained with the method proposed in this paper are expressed in carbon unit rather than in oxygen unit. This avoids to take into account in the measurement other processes, than biodegradation, which as nitrification also consume oxygen. Moreover in our method, dissolved and particulate fractions of the biodegradable matter are determined. This is an important point in the view of wastewater treatment processes design and management as the behaviour of dissolved and particulate fractions is different during treatment and also after discharge of the effluent in natural aquatic ecosystems. Ecological implications are of major importance as the water quality of rivers (oxygenation) downstream effluents outfall will depend on the fraction of biodegradable organic matter available for the heterotrophic bacteria.

\section{Acknowledgements}

The study has been partly carried out during the course of the PIREN-Seine program (Centre National de la Recherche Scientifique-CNRS- France) and partly during the course of the study : " Etude écologique d'un système fluvial perturbé (la basse Meuse) " supported by the « Fonds de la Recherche Fondamental Collective » (Belgium). The authors are indebted to A. Anzil for her excellent technical assistance.

\section{References}

Barillier A. 1992. - Caractérisation et dynamique de la matière organique d'un milieu fluvial anthropisé, la Seine. Thèse. Université de Paris VI : 104 p.

Barillier A. \& Garnier J. 1993. - Influence of temperature and substrate concentration on bacterial growth yield in Seine River water batch cultures, Appl. Environ. Microbiol., 59 : 1678-1682.

Block J.C., Mathieu L., Servais P., Fontvielle D. \& Werner P. 1992. - Indigenous bacterial inocula for measuring the biodegradable dissolved organic carbon (BDOC) in waters. Wat. Res., $26: 481-486$.

Dawson R. \& Duursma E.K. 1981. — Stade of the art. In : Marine Organic Chemistry, Duursma E.K. \& Dawson R., ed. Elsevier, Amsterdam : 497-512.

Garnier J., Servais P. \& Billen G. 1992. - Dynamics of bacterioplankton in the river Seine (France) ; impact of parisian effluents. Can. J. Microbiol., 38 : 56-64.

Hama T. \& Handa N. 1980. - Molecular weight distribution and characterization of dissolved organic matter from lake waters. Arch. Hydrobiol., 90 : 106-120.

Huck P. 1990. - Measurement of Biodegradable Organic Matter and Bacterial Growth Potential in Drinking Water, Journal $A W W A, 82: 78$.

Joret J.C. \& Levy Y. 1986. - Méthode rapide d'évaluation du carbone éliminable des eaux par voies biologiques. Trib. Cebedeau. $510: 39: 3-9$.

Ribas F., Frias J. \& Lucena F. 1991. - A new dynamic method for the rapid determination of the biodegradable dissolved organic carbon in drinking water. J. of Appl. Bacteriol., 71 : 371-376.

Servais P., Billen G. \& Hascoët M.C. 1987. - Determination of the biodegradable fraction of dissolved organic matter in waters, Wat. Res., 21 : 445-450.

Servais P., Anzil A. \& Ventresque C. 1989. - A simple method for the determination of biodegradable dissolved organic carbon in water. Appl. Environ. Microbiol., 55 : 2732-2734.

Servais P. \& Garnier J. 1993. - Contribution of Heterotrophic Bacterial Production to the Carbon Budget of the River Seine (France). Microbial Ecology, 25 : 19-33. 